\begin{tabular}{|c|c|}
\hline $\begin{array}{l}\text { Alu } 201996 \text { ENGINEERING DATA TRANSMI } \\
\text { Sta } 4\end{array}$ & 1. EDT $\quad 6182 \frac{\text { Page } 1 \text { of }}{6} \frac{1}{46}$ \\
\hline
\end{tabular}

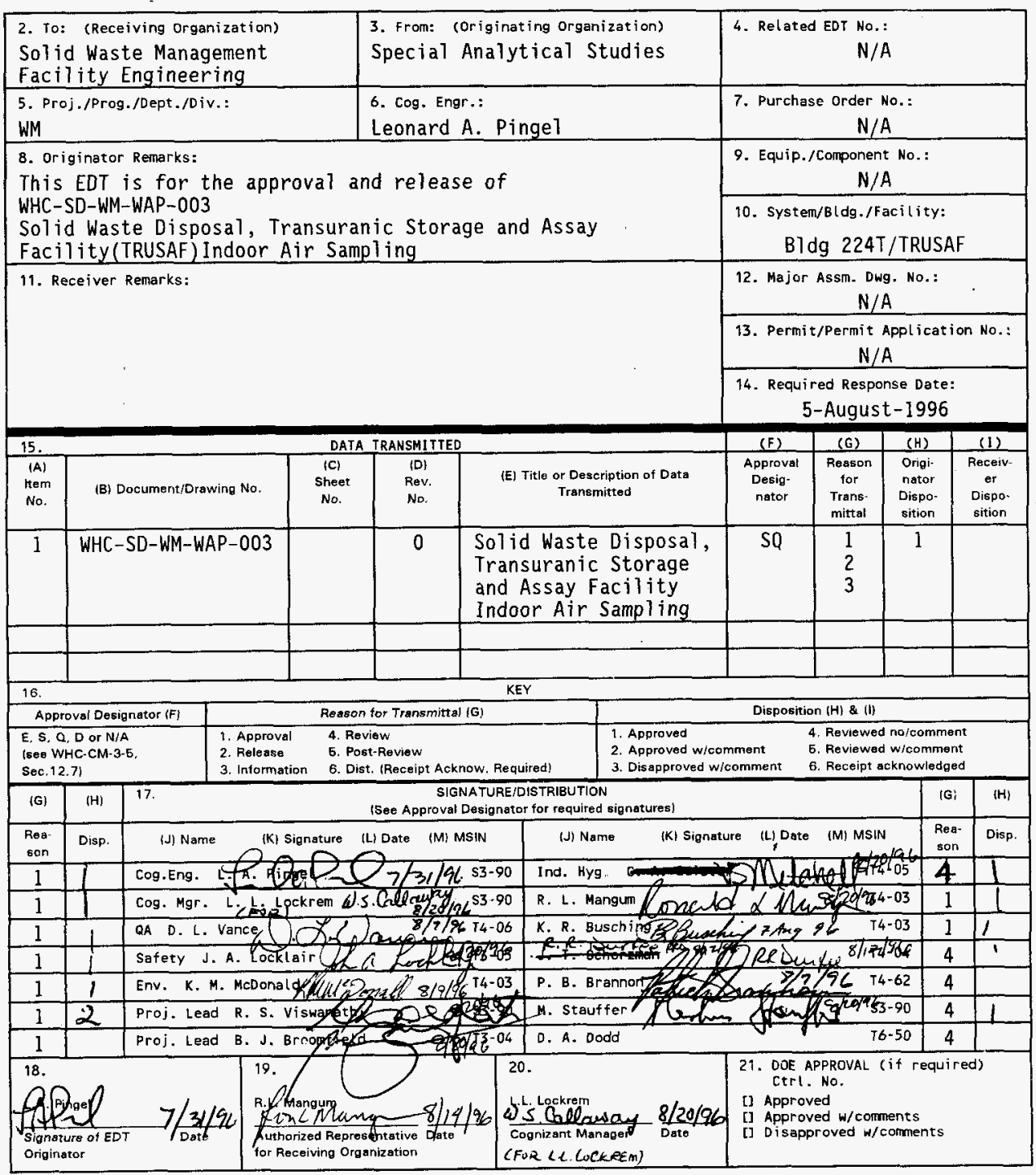

$B D-7400-172-2(04 / 94)$ GEF097 


\section{Solid Waste Disposal, Transuranic Storage and Assay Facility Indoor Air Sampling}

\section{A. Pingel}

Westinghouse Hanford, Richland, WA 99352

U.S. Department of Energy Contract DE-AC06-87RL10930

EDT/ECN: 618246

Org Code: 75745

B\&R Code: YNO100000
UC: 602

Charge Code: A3W19

Total pages: 27

Key Words: Air Sampling, Summa Analys is, US EPA, TRUSAF, 224-T

Abstract:

The purpose of the study is to collect and analyze samples of the indoor air at the Transuranic Storage and Assay Facility (TRUSAF), Westinghouse Hanford. A modified US EPA T0-14 methodology, using gas chromatography/mass spectrography, may be used for the collection and analysis of the samples. The information obtained will be used to estimate the total release of volatile organic compounds from TRUSAF to determine the need for air emmission permits.

TRADEMARK DISCLAIMER. Reference herein to any specific comercial product, process, or service by trade name, trademark, manufacturer, or otherwise, does not necessarily constitute or imply its endorsement, recommendation, or favoring by the United States Government or any agency thereof or its contractors or subcontractors.

Printed in the United States of America. To obtain copies of this document, contact: WHC/BCS Document Control Services, P.O. BOX 1970, Mailstop H6-08, Richland WA 99352, Phone (509) 372-2420; Fax (509) 376-4989.
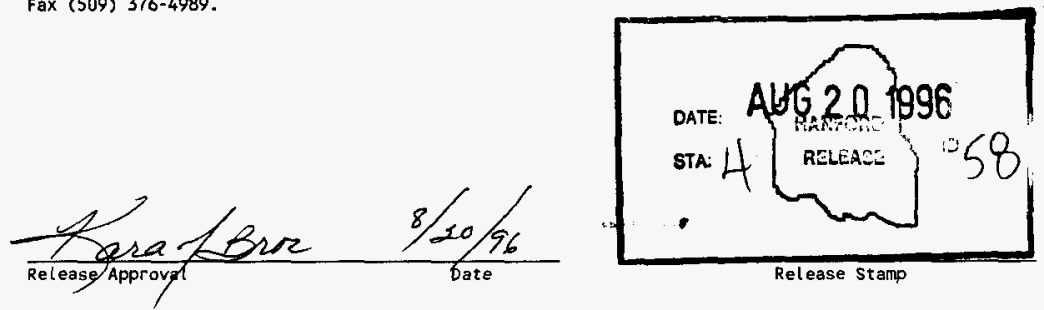

\section{Approved for Public Release}


WHC-SD-WM-WAP-003 Rev. 0

TABLE OF CONTENTS

TABLE OF CONTENTS ............................ . . .

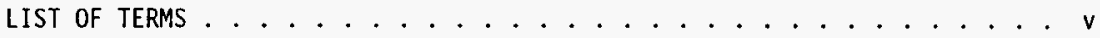

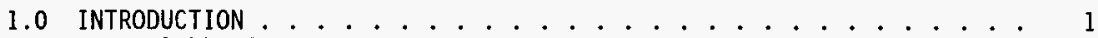

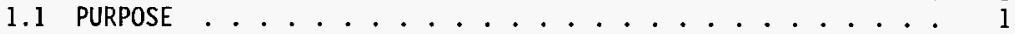

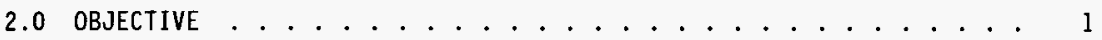

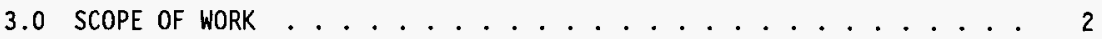

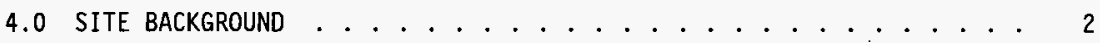

5.0 RESPONSIBILITIES . . . . . . . . . . . . . . . 3

5.1 ENGINEERING ...................... 3

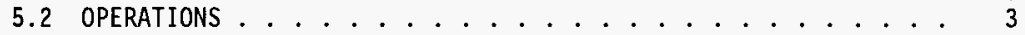

5.3 RADIOLOGICAL CONTROL . . . . . . . ...... 3

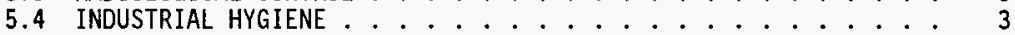

5.5 TRANSURANIC WASTE STORAGE AND ASSAY FACILITY SAFETY $\ldots \ldots$

5.6 SPECIAL ANALYTICAL STUDIES (SAMPLE COLLECTION) $\ldots . . . .4$

5.7 SPECIAL ANALYTICAL STUDIES (SAMPLE ANALYSIS) $\ldots \ldots$

5.7.1 Supply the SUMMA ${ }^{\mathrm{m}}$ Canisters . . . . . . . . . . . . . 4

5.7.2 Receive the Collected Samples ......... 4

5.7.3 Analyze the Collected Gas Samples . . . . . . . . . . 4

5.7.4 Detailed Final Reporting Identifying . . . . . . . 4

5.8 DATA REVIEW AND FINAL REPORT . . . . . . . . . . . 5

6.0 SAMPLING LOCATIONS AND FREQUENCY . . . . . . . . . . 6

6.1 SAMPLE LOCATIONS . . . . . . . . . . . . . . . . . . . . 6

6.1 .1 Trip B1anks ............... . . . 6

6.1.2 Up-Wind and Down-Wind Fenceline Samples ..... 10

6.1 .3 Ambient Air Blanks ................ 10

6.1.4 TRUSAF First Floor . . . . . . . . . . . . . . 10

6.1 .5 TRUSAF Second Floor ............... 10

6.1.6 TRUSAF Third Floor . . . . . . . . . . . . . . 10

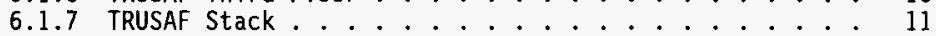

6.2 NUMBER OF SAMPLES . . . . . . . . . . . . 11

7.0 SAMPLE QUALITY ASSURANCE/QUALITY CONTROL . . . . . . . . . 12

7.1 QUALITY ASSURANCE . . . . . . . . . . . . . 12

7.2 SAMPLE LABELING . . . . . . . . . . . 12

7.2.1 Project Tracking Number . . . . . . . . 12

7.2 .2 Building Designator ............ 13 
7.2 .3 Sequence Number . . . . . . . . . . . 13

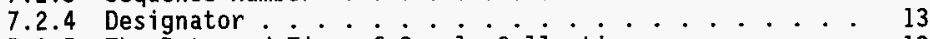

7.2.5 The Date and Time of Sample Collection....... 13

7.3 SAMPLE UNCERTAINTY . . . . . . . . . . . . 13

7.3.1 Loss of Sample Canister Vacuum . . . . . . . . 13

7.3.2 Sample Tracking . . . . . . . . . . . . . 13

7.3.3 Incorrectly Identified Sample ........... 14

7.4 SAMPLE ASSURANCE ..................... 14

7.5 METEOROLOGICAL CONSIDERATIONS ................... 14

8.0 SAMPLE HANDLING AND ANALYSIS .................... 15

8.1 SAMPLING CONDITIONS . . . . . . . . . . . . 15

8.1 .1 INDOOR SAMPLES $\ldots \ldots \ldots \ldots . \ldots \ldots$

8.1.2 STACK SAMPLES ................... . . . 15

8.2 SAMPLE CONTAINER . . . . . . ........ 15

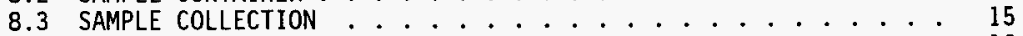

8.4 CHAIN-OF-CUSTODY . . . . . . . . . . . 16

8.5 SAMPLE TRANSPORTATION $\ldots \ldots \ldots 16$

8.6 RADIATION RELEASE . . . . . . . . . . . . . . . . . 16

8.7 SAMPLING EQUIPMENT $\ldots \ldots \ldots \ldots$

8.8 SAMPLE ANALYSIS . . . . . . . . . . . . . . . 17

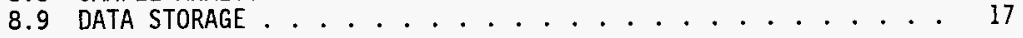

9.0 EMERGENCY PREPAREDNESS . . . . . . . . . . . . . . 17

10.0 REFERENCES ........................... 18

\section{APPENDIXES}

A ANALYTE LIST FOR QUANTIFICATION .............. A-I

B SAMPLING SCHEDULE ..................... B-1

C AIR SAMPLING FIELD DATA SHEET ................

\section{LIST OF FIGURES}

1 TRUSAF Building First Floor............... 7

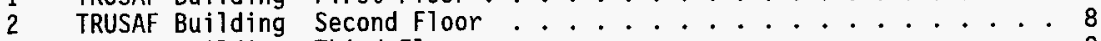

3 TRUSAF Building Third Floor ................ 9

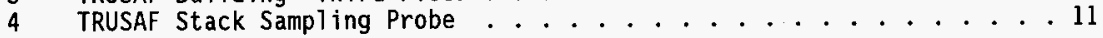

\section{LIST OF TABLES}

1 Key Individuals and Responsibilities . . . . . . . . . . 5

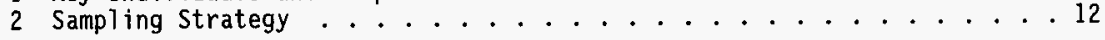


WHC-SD-WM-WAP-003 Rev. 0

\section{LIST OF TERMS}

$\begin{array}{ll}\text { DQO } & \text { Data Quality Objectives } \\ \text { LOI } & \text { Letter of Instruction } \\ \text { RWP } & \text { Radiation Work Permit } \\ \text { SAS } & \text { Special Analytical Studies } \\ \text { SWMFE } & \text { Solid Waste Management Facility Engineering } \\ \text { SWMO } & \text { Solid Waste Management Operations } \\ \text { TRUSAF } & \text { Transuranic Waste Storage and Assay Facility } \\ \text { VOC } & \text { Volatile Organic Compounds } \\ \text { WAC } & \text { Washington State Authorization Code } \\ \text { WHC } & \text { Westinghouse Hanford Company }\end{array}$


WHC-SD-WM-WAP-003 Rev. 0

\subsection{INTRODUCTION}

\subsection{PURPOSE}

The purpose of this screening study is to determine the type and concentration of volatile organic compounds (VOC) in the indoor air and exhaust stack gases/vapors at the Transuranic Waste Storage and Assay Facility (TRUSAF). This study represents an initial measurement to establish a baseline for volatile organic compounds at the TRUSAF. The analytical results of this study will attempt to address concerns regarding further analysis and need for additional sampling and analysis cycles. The information obtained may be used to estimate the total release of VOC from the TRUSAF.

\subsection{OBJECTIVE}

The objective of this study is to collect and analyze samples of the indoor air and exhaust stack gases/vapors at TRUSAF located at the 200 West Area, Hanford Site, Richland, Washington. The compounds identified in Appendix $A$ will be quantitated and/or estimated. The list of compounds in Appendix A was derived from the TRUSAF waste inventory; it includes those compounds which are on the Washington State Authorization Code (WAC) 173-460 list of Class A or Class B toxic pollutants (WAC 173-460).

The information collected from this study will be used as a method of screening the TRUSAF for organic emissions. This study is designed to identify compounds that are of potential concern for the TRUSAF.

The final report, by Special Analytical Studies (SAS), will also outline the sampling and analysis techniques and qualitative and quantitative information for the VOCs found in the indoor air samples at the TRUSAF.

The objectives of this study are outlined in the Letter of Instruction (LOI), issued as an Internal Memo, 87600-96-029, (Pierce 1996).

This SAP will address the data goals put forth by the Data Quality objectives (DQO), issued as an Internal Memo, 87600-RDP-96-005, (Pierce 1996). 


\subsection{SCOPE OF WORK}

The size of TRUSAF makes it necessary to measure the air emissions in several sampling events. This initial sampling task will consist of two or more, sampling events (see Appendix B), to establish a qualitative baseline for the facility.

Sampling Event 1. Indoor Air Sampling

Sampling Event 2. Stack Sampling

Sampling Event 3 . Further Study (if requested)

This sampling plan has been structured to obtain screening sample data within the $D Q 0$ guidelines that will identify organic yapor concerns at the TRUSAF. The data will be derived from analyzed SUMMA ${ }^{\mathrm{m}}$ canisters using methods for:

- Collecting the gas sample

- Analyzing the sample

- Analyzing the data

- $\quad$ Storing the sample and sample records.

All personnel associated with collecting and analyzing the vapor samples from the TRUSAF shall comply with the procedural guidelines related to their assigned responsibilities.

Any time after the initial sampling, Solid Waste Management may decide to negotiate a change in the total number of samples in subsequent air sampling projects.

A follow-up of this limited sampling and analysis effort may be conducted to determine seasonal variations in VOC concentrations. Additional sampling may be planned to further investigate a targeted set of VOCs and to identify the specific sources for individual vocs.

\subsection{SITE BACKGROUND}

The Hanford TRUSAF is an existing facility for the storage of transuranic solid waste materials under the management of Solid Waste Disposal Division at the Hanford Site. The TRUSAF has three floors which are used for

${ }^{1}$ SUMMA is a trademark of Molectrics, Inc., Cleveland, $\mathrm{OH}$. 
the storage of transuranic and/or mixed waste. There is an extensive and comprehensive exhauster system which exhausts the indoor air from the building.

\subsection{RESPONSIBILITIES}

\subsection{ENGINEERING}

Solid Waste Management Facility Engineering (SWMFE) shall develop and approve the facility work documentation for this sampling effort.

\subsection{OPERATIONS}

Solid Waste Management Operations (SWMO) will control access and ensure all sampling operations are completed in accordance with the applicable approved work plan.

\subsection{RADIOLOGICAL CONTROL}

Provide Health Physics support needed for the sampling of the TRUSAF area.

Radiological control will provide the necessary radiation work permits (RWPs) needed for collecting indoor and ambient air sample in the TRUSAF area.

\subsection{INDUSTRIAL HYGIENE}

Support the sampling event by monitoring the air contained within the air space to be sampled for oxygen content and organic vapor concentrations. Industrial Hygiene will be expected to follow any monitoring protocol specified in WHC-CM-4-40, Industrial Hygiene Manual.

\subsection{TRANSURANIC WASTE STORAGE AND ASSAY FACILITY SAFETY} Manager.

Safety planning will be the responsibility of the Solid Waste Safety

Site Safety will oversee the operation and ensure the procedural steps for the sample collection meet any site safety requirements as outlined in WHC-CM-1-10, Safety Manua7, and WHC-CM-4-40, Industrial Hygiene Manual. 


\subsection{SPECIAL ANALYTICAL STUDIES (SAMPLE COLLECTION)}

Supply any specialized sampling device and any validation testing for its operation in a controlled logbook, WHC Laboratory notebook WHC-N-669-1; Sampling Methods Development (McClellan 1992). The materials used to fabricate any device used for the collection of these samples will be from available off-the-shelf merchandise.

Collecting samples and reporting field analysis will be in accordance with the sampling procedure, WHC-IP-1128, Section 4.6, Collection of SUMMA Canisters Samples (Lockrem 1995).

Sampling activities are documented in a WHC controlled $\log$ book.

A sampling report will be submitted reporting all activities and any off-normal events.

\subsection{SPECIAL ANALYTICAL STUDIES (SAMPLE ANALYSIS)}

\subsubsection{Supply the SUMMA ${ }^{\text {TM }}$ Canisters}

Supply and oversee the SUMMA canisters as follows.

- Maintain a historical sampling and cleaning log for each canister.

- Evacuate to a pressure of $<150^{2}$ mtorr.

- Initiate chain-of-custody.

\subsubsection{Receive the Collected Samples}

The collected samples will be received.

\subsubsection{Analyze the Collected Gas Samples}

- Qualitative Analysis of samples.

- Quantitative Analysis of compounds identified in Appendix A.

\subsubsection{Detailed Final Reporting Identifying}

A detailed final report will identify the following.

2 Specified in US EPA TO-14 method that canisters are evacuated to $<50$ mtorr 


\section{WHC-SD-WM-WAP-003 Rev. 0}

- Identified Compounds and Estimated Concentrations

- Instrumental Analysis Procedure

- Calibration Information.

\subsection{DATA REVIEW AND FINAL REPORT}

Special Analytical Studies will compile the data collected and assemble a final sampling and analysis report consisting of the following:

- Field Sampling Information

- Analytical Results.

Table 1. Key Individuals and Responsibilities Individual Organization

Responsibility

\begin{tabular}{||l|l|l||}
\hline B.J. Broomfield & Waste Acceptance Services & Project Lead \\
\hline R.S. Viswanath & Special Analytical Services & Project Lead \\
\hline L.A. Pingel & Special Analytical Studies & Field Scientist \\
\hline M. Stauffer & Special Analytical Studies & Analyst \\
\hline R.L. Mangum & SWM Facilities Engineering & Facility Engineer \\
\hline E.J. Millikin & Solid Waste Radiological Cntrl & Health Physicist \\
\hline J.A. Lockliar & Solid Waste Management Nuclear Safety & Safety Engineer \\
\hline R.R. Durfee & Solid Waste Mgmt Facility Ops & Operations \\
\hline
\end{tabular}




\subsection{SAMPLING LOCATIONS AND FREQUENCY}

The air sample locations at TRUSAF, where air samples will be collected, are a function of the general floor area and the material storage areas.

- First floor-receiving/initial storage, Size: $567 \mathrm{~m}^{2}(6100) \mathrm{ft}^{2}$."

- Second floor-transuranic/mixed waste, $520 \mathrm{~m}^{2}(5600) \mathrm{ft}^{2}$."

- Third floor-transuranic waste/caustics, $305 \mathrm{~m}^{2}$ (3275) $\mathrm{ft}^{2}$."

- Stack (Roof Top)-exhaust gases/vapors. 269 kLPM (9500 CFM)*

* All area and volumes are approximate

The sample collection strategy for this sampling event is designed to optimize the conditions for collecting organic vapors. For example, the strategy for the main building is different from the exhauster stack, which is described in the Sections 6.1.4 through 6.1.7.

\subsection{SAMPLE LOCATIONS}

The location of each collected sample will be noted in the sampling logbook/data sheets. The information collected will contain the following, (refer to figures $1-3$ ):

- Noting the position of the sample and the room number.

- Identifying the sample number of the sample collected.

- Describing the area where the sample is collected.

\subsubsection{Trip Blanks}

A quality assurance trip blank will accompany each sampling event. This canister will be carried into the field, and returned to the analyzing laboratory as an evacuated canister. The laboratory will fill the canister with zero grade air, measure the contaminants and use the analytical results as a background reference. 
WHC-SD-WM-WAP-003 Rev. 0

Figure 1. TRUSAF Floor 1.

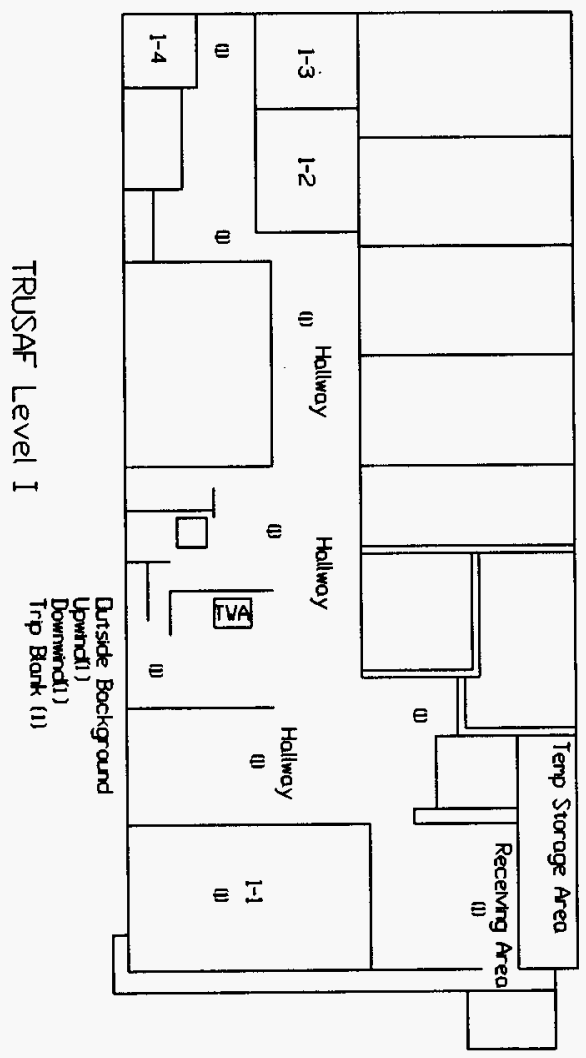


WHC-SD-WM-WAP-003 Rev. 0

Figure 2. TRUSAF Floor 2.

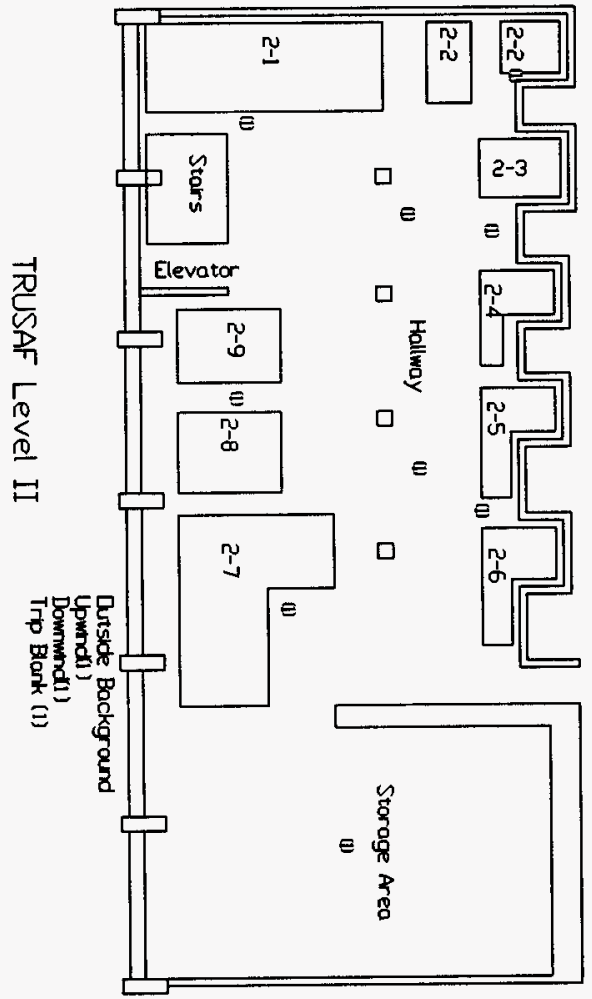


WHC-SD-WM-WAP-003 Rev. 0

Figure 3. TRUSAF Floor 3.

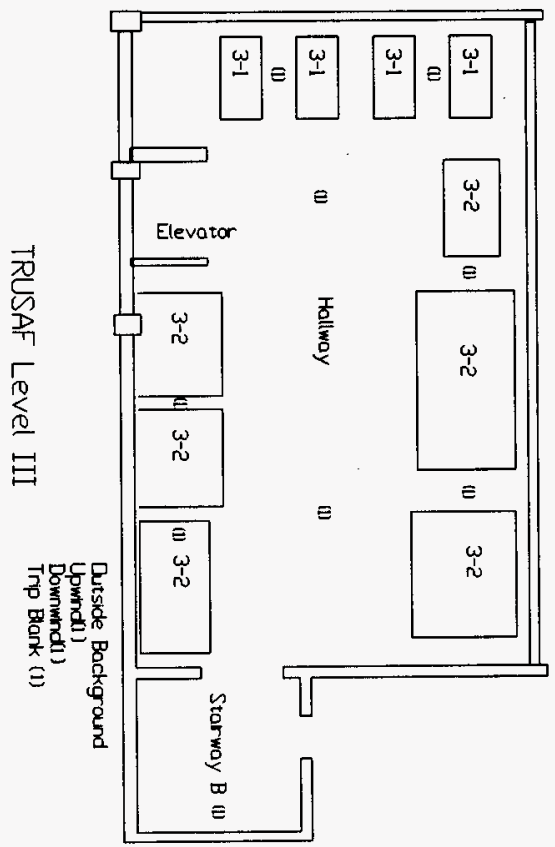




\subsubsection{Up-Wind and Down-Wind Fenceline Samples}

Two fence-line samples, with duplicates, will be taken each sampling day and with the assumption that these samples represent the air entering and exiting the TRUSAF area during sampling. These samples will be taken at upwind and down-wind fence lines relative to the building being sampled.

Only one set of up-wind and down-wind samples (two samples) will be collected for sampling of all the three floors of TRUSAF because the sampling is expected to be complete in one day as per the schedule in Table 2.

\subsubsection{Ambient Air Blanks}

Ambient air blanks will be taken approximately five meters ( 200 inches) directly upwind of the building that is being sampled. The canister will be held at an elevation between one and two meters from the ground, in the breathing zone of the sampling personnel.

The date of the ambient air sample collection event should correspond with the date the samples being collected within the building. The position of each ambient air sample will be accurately documented and will be at the discretion of the SAS sampling lead.

\subsubsection{TRUSAF First Floor}

Nine indoor air samples will be collected at various points with in the air space of the first floor. The approximate sample locations are indicated in Figure 1. The sampling points are: one in the receiving area, one in area 1 , one near the hood area, one in front of a staircase near receiving area, one at the TWA area, one close to Assayer control room, one in the hallway by mechanical room and two in the hallway between areas 2,3 and 4 . One duplicate sample will be collected for quality control and quality assurance (QA/QC).

\subsubsection{TRUSAF. Second Floor}

Nine indoor air samples will be taken at various points within the air space of the second floor. The position of each sample point is described in Figure 2. The sampling points are: one in the large storage area, two in the long hallway, one in front of and close to area 7, one between areas 8 and 9 , one close to area 1 , one between areas 3 and 4 , one between areas 5 and 6 , and one in area 2. One duplicate sample will also be collected for $Q A / Q C$.

\subsubsection{TRUSAF Third Floor}

Nine indoor air samples will be taken at various points within the air 
space of the third floor. The position of each sample point is described in Figure 3. The sampling points are: one in the stairway B area, a total four in area 2 spaces, two in area 1 spaces, and two in the main hallway. One duplicate sample will also be collected for $Q A / Q C$.

\subsubsection{TRUSAF Stack}

A total of seventeen samples will be collected for the baseline study of TRUSAF exhaust stack emissions. The samples will be continuously collected for a period of 24 hours, one full day, at the rate of one canister sample per 2 hour interval. All the samples collected from the exhaust gases/vapors will be two-hour integrated samples. In addition, two fenceline samples will be collected the day of the sampling event. One trip blank sample will be used.

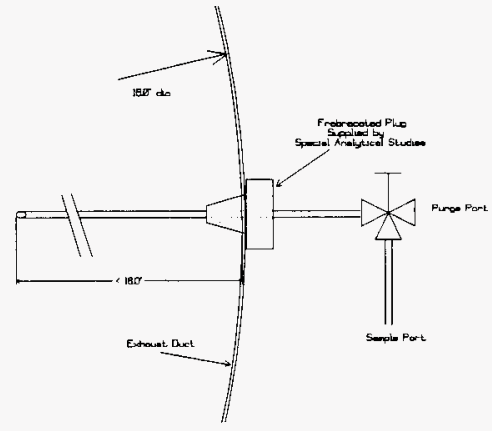

Sampling Probe Positioned in the TRUSAF Exhaust Stack
A sampling probe, 1/8" SS tubing, will be positioned into the exhaust flow of the TRUSAF exhaust stack. A sample will draw sample gas out and fill a SUMMA canister matrix. After twelve hours the SUMMA matrix will be replaced with a new set of canisters. Existing radiological monitoring will be in place and operational during the TRUSAF exhaust sampling.

The sampling process will be automated such that after initial setup there may only need to be intervention after the 12 hour sampling period.

\subsection{NUMBER OF SAMPLES}

In general, ten percent of the total number of the samples in each sampling event will be collected in duplicate. and analyzed for Quality Assurance and Quality Control purposes. One trip blank per day will be used for background contamination checks. In addition, one set of up-wind and down-wind fenceline samples will be collected. 
Table 2. Sampling Strategy.

\begin{tabular}{|l|c|c|c|}
\hline SAMPLING SITE & $\begin{array}{l}\text { NUMBER OF } \\
\text { SAMPLES }\end{array}$ & $\begin{array}{l}\text { NUMBER OF } \\
\text { BLANKS }\end{array}$ & TOTAL SAMPLES \\
\hline $\begin{array}{l}\text { TRUSAF First } \\
\text { Floor }\end{array}$ & $\begin{array}{c}9 \text { samples }+ \\
1 \text { duplicate }\end{array}$ & $\begin{array}{l}1 \text { upwind }+ \\
1 \text { downwind }+ \\
\text { trip blank }\end{array}$ & 13 \\
\hline $\begin{array}{l}\text { TRUSAF Second } \\
\text { Floor }\end{array}$ & $\begin{array}{c}9 \text { samples }+ \\
1 \text { duplicate }\end{array}$ & 0 & 10 \\
\hline $\begin{array}{l}\text { TRUSAF Third } \\
\text { Floor }\end{array}$ & $\begin{array}{c}9 \text { samples }+ \\
1 \text { duplicate }\end{array}$ & 0 & 10 \\
\hline TRUSAF Stack & $\begin{array}{l}12 \text { samples }+ \\
2 \text { duplicate } \\
1 \text { dupwind }+ \\
\text { downind }+\end{array}$ & 17 \\
\hline TOTAL & 44 & 6 & 50 \\
\hline
\end{tabular}

\subsection{SAMPLE QUALITY ASSURANCE/QUALITY CONTROL}

\subsection{QUALITY ASSURANCE}

Procedural Quality assurance will be in accordance with the applicable referenced documents in the sampling and analysis plan.

\subsection{SAMPLE LABELING}

Unique sample identification numbers shall be assigned to each sample by special analytical studies, WHC, that identify the following.

\subsubsection{Project Tracking Number}

A referenced identification number assigned by SAS that is unique to the TRUSAF sampling job. 


$$
\text { WHC-SD-WM-WAP-003 Rev. } 0
$$

\subsubsection{Building Designator}

taken.

A three digit number that represents the floor where the air sample was

\subsubsection{Sequence Number} taken.

A number that represents the chronological order in which the sample was

\subsubsection{Designator}

The letter "A" designates the primary sample.

The letter "B" designates the secondary sample.

\subsubsection{The Date and Time of Sample Collection}

\section{Sample Identification Number Example:}

$$
\text { FTxxx flr/stk. nn(A or B) }
$$

Where:

$\begin{array}{llll}\text { FTxxxx } & = & \text { Project Tracking Number } & \text { FT6099 } \\ \mathrm{flr} / \mathrm{stk} & = & \text { Floor } / \text { Stack Designator } & 2 \\ \mathrm{nn} & = & \text { Sequence Number } & 34 \\ \mathrm{~A} \text { or B } & = & \text { First or Second Designator } & \text { A }\end{array}$

\subsection{SAMPLE UNCERTAINTY}

\subsubsection{Loss of Sample Canister Vacuum}

The sample collection canisters will be received by the sampling team from the analytical laboratory. The evacuated canisters can hold a vacuum for greater than 14 days. The evacuated sample canisters will not be allowed to sit for longer than 14 days. If that happens, the canisters must be cleaned and evacuated again before being used.

\subsubsection{Sample Tracking}

Each sample canister will be permanently marked by a unique stee? stamped number. This unique identification number wil1 be used to track the sampling and cleaning history each canister. This canister number will also be on the affixed sample tag. 


\subsubsection{Incorrectly Identified Sample}

During the sampling event, the steel stamped canister will be assigned to a mapped location within the sampling area. Before the sample can be taken, a second observer must check the canister identification and its mapped location.

\subsection{SAMPLE ASSURANCE}

Any marks or identification of the sample canister will be applied after the sample has been taken. The sample gas collected will therefore be devoid of any organic compounds that are the result of marking material off-gassing during sampling.

The individual(s) responsible will be dressed in company provided clean blue coveralls. These personnel will not be wearing any type of applied fragrance the day of the sampling event.

No canister witl be moved from TRUSAF until all sample canisters, from a given sampling event, have been filled with sample air or until the designated activity is completed.

For this project, a sample hold time of 14 calendar days will be used. Samples that are held for longer than 14 days will be analyzed at the discretion of the SAS Project Lead.

\subsection{METEOROLOGICAL CONSIDERATIONS}

The predominant wind direction for the summer months at the Hanford Site is north northwest (NNW) as reported by the Hanford Site Meteorological Station, Pacific Northwest National Laboratory (Stone, 1983). Wind direction and wind speed will be noted in the sampling notes/log for the corresponding samples. The wind consideration is important due to the Hanford Site's high level mixed waste tanks being located south of the TRUSAF.

At the time of sampling, if weather conditions are unfavorable, the sampling activity might have to be delayed at the discretion of the SWMFE engineer and/or the SAS sampling lead. 


\subsection{SAMPLE HANDLING AND ANALYSIS}

\subsection{SAMPLING CONDITIONS}

The indoor conditions at the TRUSAF are typically constant such that there is no need to specify any sampling conditions.

\subsubsection{INDOOR SAMPLES}

The indoor air samples will be collected under static conditions. Solid Waste Management Facility Engineering will arrange to turn off the TRUSAF ventilation system a minimum of 16 hours prior to the sampling event. Stopping the active ventilation should allow optimum conditions for collection of any increased concentration of VOCs in the building.

\subsubsection{STACK SAMPLES}

The stack exhaust samples will be collected from the exhaust gases/vapors when the ventilation system is on.

\subsection{SAMPLE CONTAINER}

Special Analytical Studies will collect the air samples using evacuated SUMMA canisters. Each canister will be cleaned and evacuated to less than 150 mtorr prior to use. For this project, a minimum of $10 \%$ of the cleaned canisters will be selected at random and analyzed for canister cleanliness checks.

A database will be used to follow each canister throughout the entire sampling event. This canister monitoring will be used for assessing potential carry-over between sampling events.

\subsection{SAMPLE COLLECTION}

Each sample device will be placed in its respective position by a member of the SAS sampling team. The sample identification tag will be attached prior to the sample collection.

In each sampling event, the samples will be collected in a continuous manner once sampling has started.

The sampling responsibilities of SAS will be addressed in the operating 
procedures, WHC-IP-1128, Section 4.6.

An Air Sampling Field Data Sheet (Appendix C) will be used for each sample collected within the TRUSAF facility.

\subsection{CHAIN-OF-CUSTODY}

Transporting any collected sample to the designated analytical laboratory SAS will use Westinghouse Hanford Company (WHC) chain-of-custody protocol, WHC-1P-1128 Section 1.15, Rev 0, Chain of Custody/Sample Analysis Request for RCRA/CERCLA Protocol Samples.

\subsection{SAMPLE TRANSPORTATION}

The samples collected will be transported to the analyzing laboratory by SAS or Sampling and Mobile Laboratories.

The samples will be received by the analyzing laboratory within 24 hours of collection.

\subsection{RADIATION RELEASE}

Normal ambient airborne concentrations of particulate radionuclides within the TRUSAF indoor air have been shown to be below the levels of concern. (Fishburn, 1996).

Weekly particulate air sampling is performed to verify radioactive contamination levels. Historically, information collected during weekly air sampling has shown elevated levels of radon.

No release is required for equipment/material that has never been used or stored in a contamination area, high contamination area, airborne radioactivity area, or radiological buffer area established for unsealed radioactive sources, WHC-IP-0718 Section 3.1.1, Rev. 4, Health Physics Policy and Procedures (Mallory 1993). There are no uncontained radiological contamination area at the TRUSAF; therefore, radiological release of the vapor sampling canisters, supporting this sampling activity, is not required.

If radiation release is required, then release of canisters will have to be performed by the Health Physics personnel, following the appropriate established protocols of sample release.

\subsection{SAMPLING EQUIPMENT}

The equipment used for the sampling will be passivated SUMMA canisters 
as accepted by the US EPA for organic vapor sampling.

\subsection{SAMPLE ANALYSIS}

Special Analytical Studies will analyze the collected SUMMA samples using a modified US EPA TO-14 procedure (Winberry, et.a1. 1990).

A random sampling of $\geq 10 \%(1: 10)$ of any collected duplicate samples, per sampling event, will be analyzed as a part of quality control and quality assurance.

\subsection{DATA STORAGE}

Special Analytical Studies will maintain a long term storage facility for the storage of the collected data. The storage facility will be maintained in accordance with WHC-CM-3-5, Document Control and Record Management Manual.

\subsection{ENERGENCY PREPAREDNESS}

Sampling personnel will contact the Waste Management Facility shift manager and the person-in-charge for guidance in emergency preparedness in support of gas sampling. 


\subsection{REFERENCES}

Fishburn, M. R., 1996, Annual Reassessment of Transuranic Waste Storage and Assay Facility for Compliance with Workplace Air Sampling and Monitoring, (letter 96-33540-001 to P. B. Brannan), Westinghouse Hanford Company, Richland, Washington.

Lockem, L.L., 1995, Special Analytical Studies Procedure Manual, WHC-IP-1128, Rev. 0, Section 1.15, "Chain of Custody/Sample Analysis Request for RCRA/CERCLA Protocol Samples" and Section 4.6, "Collection of SUMMA Canister Samples", Westinghouse Hanford Company, Richland, Washington.

McClellan, C. S., 1992, Sampling Methods Development, WHC Laboratory Notebook WHC-N-669-1, Westinghouse Hanford Company, Richland, Washington.

Mallory, W.C., 1993, Health Physics Policy and Procedures, WHC-IP-0718, Westinghouse Hanford Company, Richland, Washington.

Pierce, R. D., 1996, Letter of Instruction for the Sampling and Analysis of Ambient and Exhaust Air at the Transuranic Storage and Assay Facility, (internal memo 87600-RDP-96-029 to L. L. Lockrem, July 1996), Westinghouse Hanford Company, Richland, Washington.

Pierce, R. D., 1996, Data Quality 0bjectives (DQ0), (InternaT Memo, 87600-RDP96-005 to Larry Lockrem, March 5) Westinghouse Hanford Company, Richland, Washington.

Stone, W. A., 1983, Climatological Summary for Hanford Area, PNL-4622-UC-11, Pacific Northwest Laboratory, Richland, Washington.

WAC 173-460, 1990, "Controls for New Sources of Toxic Air Pollutants," Washington Administrative Code, as amended.

Winberry, W.T., T. N. Murphy, and R. M. Riggan, 1990, Methods for Determination of Toxic Organic Compounds in Air: EPA Methods, Noyes Data Corporation, Park Ridge, New Jersey.

WHC-CM-1-10, Safety Manual, Westinghouse Hanford Company, Richland, Washington.

WHC-CM-3-5, Document Control and Record Management Manual, Westinghouse Hanford Company, Richland, Washington.

WHC-CM-4-2, Quality Assurance Manual, Westinghouse Hanford Company, Richland, Washington. 
WHC-SD-WM-WAP-003 Rev. 0

WHC-CM-4-40, Industrial Hygiene Manual, Westinghouse Hanford Company, Richland, Washington. 
WHC-SD-WM-WAP-003 Rev. 0

\section{APPENDIX A}

ANALYTE LIST FOR QUANTIFICATION

\begin{tabular}{|l|c|}
\hline \multicolumn{1}{|c|}{ VOLATILE ORGANIC COMPOUNDS EXPECTED AT TRUSAF } \\
\hline \multicolumn{1}{|c|}{ Compound } & CAS \\
\hline 2-butanone (Methyl ethyl ketone) & $78-93-3$ \\
\hline 4-methyl-2-pentanone (Methyl i sobutyl ketone) & $108-10-1$ \\
\hline 2-Propanone (Acetone) & $67-64-1$ \\
\hline Benzene & $71-43-2$ \\
\hline Benzene, 1,3,5-trimethyl- & $108-67-8$ \\
\hline Benzene, 1,2-dichloro- & $95-50-1$ \\
\hline 1,1,2-Trichlorotrifluoroethane (Halocarbon 113) & $75-13-1$ \\
\hline Benzene, 1,2,4-trimethyl- & $95-63-6$ \\
\hline Benzene, 1,3-dichloro- & $541-73-1$ \\
\hline Benzene, 1,4-dichloro- & $106-46-7$ \\
\hline Benzene, chloro- & $108-90-7$ \\
\hline Benzene, ethyl- & $100-41-4$ \\
\hline Benzene, methyl- (Toluene) & $108-88-3$ \\
\hline Carbon tetrachloride & $56-23-5$ \\
\hline Chloroform & $67-66-3$ \\
\hline Cyclohexane & $110-82-7$ \\
\hline Ethane, 1,1,1-trichloro- & $71-55-6$ \\
\hline Ethane, 1,1,2,2-tetrachloro- & $79-34-5$ \\
\hline Ethane, 1,1,2-trichloro- & $79-00-5$ \\
\hline Ethane, 1,1-dichloro- & $75-34-3$ \\
\hline Ethane, 1,2-dichloro- & $107-06-2$ \\
\hline Ethanol & $64-17-5$ \\
\hline Ethene, 1,2-dichloro- (Dichloroethylene) & $156-59-2$ \\
\hline
\end{tabular}


WHC-SD-WM-WAP-003 Rev, 0

\begin{tabular}{|l|c|}
\hline \multicolumn{1}{|c|}{ VOLATILE ORGANIC COMPOUNDS EXPECTED AT TRUSAF } \\
\hline \multicolumn{1}{|c|}{ Compound } & CAS \\
\hline Ethene, 1,1-dichloro- & $75-35-4$ \\
\hline Ethene, chloro- (Vinyl chloride) & $75-01-4$ \\
\hline Ethene, tetrachloro- (Tetrachloroethylene) & $127-18-4$ \\
\hline Hexane & $110-54-3$ \\
\hline Iso-butane (2-Methyl propane) & $72-28-5$ \\
\hline Methane, dichloro- (Methylene chloride) & $75-09-2$ \\
\hline n-Butanol & $71-36-3$ \\
\hline Styrene & $100-42-5$ \\
\hline Tetrahydrofuran & $109-99-9$ \\
\hline Xylene, m- & $108-38-3$ \\
\hline Xylene, 0- & $95-47-6$ \\
\hline 2 Propanol & $67-63-0$ \\
\hline Ethene, trichloro- (Trichloroethylene) & $79-01-6$ \\
\hline $\begin{array}{l}\text { ComMENTS: } \\
\text { 2) not specified 1,1 or 1,2-Dichloroethane }\end{array}$ \\
\hline
\end{tabular}


WHC-SD-WM-WAP-003 Rev. 0

APPENDIX B

SAMPLING SCHEDULE

\begin{tabular}{|c|c|c|c|c|}
\hline \multicolumn{5}{|c|}{$\begin{array}{l}\text { SAMPLING AND ANALYSIS OF INDOOR AIR AT THE TRANSURANIC WASTE STORAGE and } \\
\text { ASSAY FACILITY: } \\
\text { TENTATIVE SAMPLING SCHEDULE }\end{array}$} \\
\hline Sampling & Analys is & Reporting & Buildings & Comments \\
\hline July 29 & JuTy 30 - Aug 9 & & $\begin{array}{l}\text { TRUSAF First } \\
\text { Floor }\end{array}$ & Samples 1-10 \\
\hline July 29 & July 30 - Aug 9 & & $\begin{array}{l}\text { TRUSAF } \\
\text { Second Floor }\end{array}$ & Samples $11-20$ \\
\hline July 29 & July 30 - Aug 9 & & $\begin{array}{l}\text { TRUSAF Third } \\
\text { Floor }\end{array}$ & Samples 21-30 \\
\hline July 29 & JuTy 30 - Aug 9 & & $\begin{array}{l}\text { up-wind, } \\
\text { down-wind } \\
\text { trip blank }\end{array}$ & Samples $31-30$ \\
\hline Aug 12 & Aug 13 - Aug 23 & & TRUSAF Stack & Samples $34-46$ \\
\hline Aug 12 & Aug 13 - Aug 23 & & $\begin{array}{l}\text { upwind, } \\
\text { downwind, } \\
\text { trip blank }\end{array}$ & Samples $47-50$ \\
\hline Aug 30 & & preliminary & & \\
\hline
\end{tabular}


WHC-SD-WM-WAP-003 Rev. 0

\section{APPENDIX C}

AIR SAMPLING FIELD DATA SHEET

Sample No.

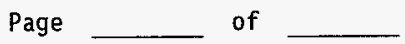

Air Sampling Field Data Sheet

Transuranic Waste Storage and Assay Facility Air Sampling

Second's Initial

Date

Sampling Lead

Sampling Second

Floor

Sample Can Number

Sample Number

Descriptive Location:

Time of sample collection

Approximate elevation during sampling

Sample Collected (initial)

Field Notes: 


\section{DISTRIBUTION SHEET}

\begin{tabular}{|c|c|c|c|c|c|}
\hline To & \multirow{2}{*}{\multicolumn{3}{|c|}{$\begin{array}{l}\text { From } \\
\text { Special Analytical Studies }\end{array}$}} & \multicolumn{2}{|l|}{ Page 1 of 1} \\
\hline $\begin{array}{l}\text { Solid Waste Management Facility } \\
\text { Engineering }\end{array}$ & & & & \multicolumn{2}{|c|}{ Date July 24, 1996} \\
\hline \multicolumn{4}{|l|}{ Project Title/Work Order } & \multicolumn{2}{|c|}{ EDT No. 618246} \\
\hline \multicolumn{4}{|c|}{$\begin{array}{l}\text { Solid Waste Disposal, Transuranic Storage and Assay } \\
\text { Facility(TRUSAF) Indoor Air Sampling }\end{array}$} & \multicolumn{2}{|l|}{ ECN No. } \\
\hline Name & MSIN & $\begin{array}{c}\text { Text } \\
\text { With All } \\
\text { Attach. }\end{array}$ & Text Only & $\begin{array}{l}\text { Attach./ } \\
\text { Appendix } \\
\text { Only }\end{array}$ & $\begin{array}{l}\text { EDT/ECN } \\
\text { Only }\end{array}$ \\
\hline
\end{tabular}

B. J. Broomfield

D. L. Vance

D. A. Dodd

D. B. Powell

K. M. McDonald

L. L. Lockrem

L. A. Pingel

M. Stauffer

P. J. Crane

P. B. Brannan

J. T. Schorzman

J. A. Locklair

R. J. Giroir

R. L. Mangum

R. S. Viswanath

V. S. Mitchell

K. R. Busching

C. A. Geisler
T3-04

T4-06

T6-50

T4-03

T4-03

$53-90$

$53-90$

$53-90$

T4-03

T4-62

T4-04

T3-05

T4-05

T4-03

S3-90

T3-05

T4-03

T4-05 